\title{
ISLAMIC MYSTICISM AND the Paradigm of Fitrah
}

\author{
Ammar Fauzi \\ The Islamic College, Jakarta, Indonesia
}

It is expected that in the contemporary world, the amount of desperate need and great optimism could be reasonably considered in order to clarify, for example, how important and relevant theoretical Islamic Mysticism is to the contemporary world? Could Sufism be useful to deal with problems of today's humanity? And how can the establishment of Islamic Mysticism be explained in non-technical terms?

That will be the subject of this paper - to consider factors such as exclusiveness and extremism, suspected potentially as the main obstacles in an effort to materialize the noble doctrines of Theoretical Mysticism, to actualize them into people's day-to-day life and to manifest the values of haqiqa as the essence of their lifestyle in such a way that thay provide the vast opportunities for their accessibility and achievement of haqiqa, at least through two introductory questions: for what and for whom Theoretical Mysticism is.

To theoretically introduce the mystical experience through an approach of innate love was prioritized here as an initial pace to unearth the real possibility of founding a new paradigm based on fitrah through the efforts of extracting mystics theoretical teachings from the scope of exclusiveness in such a way that they are accessible to inclusive human being by two phases: to back into the main line, namely, the principle of knowing the self, and secondly, to probe so deep into the nucleus of this principle so as to reach fitrah as an inexhaustibly rich source of human perfection in order to take the first step, to convoy the spiritual itinerary and to finally have the divine vision of the Truth.

Keywords: fitrah, Theoretical Mysticism, love, knowing the self, exclusiveness, extremism, dialectics.

Corresponding author: ammarfauzi@yahoo.com 
In the Islamic tradition, there are three basic terms that presumably can represent a general classification of disciplines, perspectives, methods, and even schools of thought that have been developing in it - sharia, tariqa, and haqiqa. These are not necessarily considered as dichotomous parts, but all of them can be placed completely so that they are aligned in the vertical line and complementary form as one of Islamic Mysticism principles insisting that a mystic gets a start accompanying shari'a and passes through tariqa in order to achieve haqiqa.

The last two parts, namely, tariqa and haqiqa, especially correspond to practical dimension or what is also called the itinerary of the spiritual path (sayr wa sulu k) and theoretical dimension (nadhar). It is sometimes assumed that there is a difference of meaning in the use of the two terms: sūf $\bar{\imath}$ and 'ärif, in which the first refers to wayfarer (sālik) of tariqa and haqiqa at once, while the second is known as an achiever or a philosopher of haqiqa. In the prologue of Mishbāh al-Uns, Fanari (1984: 27) has identified the practical as Sufism and the theoretical as the science of haqiqa (reality) instead.

Before Fanari, there was of course variety of terminology related to these aspects known further as Practical Mysticism ('irfän 'amalī) and Theoretical Mysticism ('irfän nazdarī). The former can be defined as the set of normative practices and mental states in the form of stations ending with the highest achievement of human's perfection, while the latter is considered as a description of reality and a science of oneness, namely, the unity of being and its implications achieved by a mystic through his summit experiences in reference to the Reality (Yazdahpanah 2009: 34).

This short prologue is not to be designed as an excuse to typically engage further upon examining the complementary patterns of trilogy: what will be the subject of this paper is to consider the array of factors suspected potentially as the main obstacles in an effort to materialize the noble doctrines of Islamic Theoretical Mysticism, to actualize them into people's day-to-day life and to manifest the values of haqiqa as the essence of their lifestyle in such a way that they provide the vast opportunities for accessibility and achievement of haqiqa, at least through two introductory questions: for what and for whom Theoretical Mysticism is. Unlike the subject of themes, issues, methods and history of Islamic Theoretical Mysticism, it looks that its practical function hasn't been properly observed yet in the Philosophy of Mysticism or, at least, in the introductory section of classically Islamic sciences known commonly as the Eight Basics (ru'üs tsamāniyah). 


\section{Exclusiveness}

A glance description of the practical function of Islamic Theoretical Mysticism could be found mainly in the prologue or epilogue parts of mystics' works. They usually made commitment for themselves to doing something, namely, beginning or ending their own works with an alarm accompanied by various accentuations. In Miftāh al-Ghayb as one of the classic references of Islamic Theoretical Mysticism, Sadruddin Qunawi (1984: 34) wrote, "Know that this book is not provided for the general public, not even for the specials, but for a circle which was the core of specials, and it would be useful to them in all the spiritual itinerary (sulük) and before reaching their goals.'

It was not unusual among Muslim mystics that there was a kind of intellectual strata in Theoretical Mysticism, and it should be considered crucial in an effort to be fair intellectually. Not everyone has got the same capacity so not all of people have sufficient eligibility to accommodate truths derived by mystics from their own experience upon the Reality. Throughout Qunawi's earlier view, his account of the unity of being (wahdat al-wujūd) has not been intended but for only a handful of people occupying three levels of intellectual-spiritual above the average common people. In a more complicated classification, we would see how Syihabuddin Suhrawardi (1994: II/11-13) summarized his mystical experiences in the magnum opus Hikmat al-Ishräq and solely dedicated it to the third of the eight classes of theosophists (hukamā'). In this classification, Qunawi's earlier criteria for a mysticism student are not in fact lower than the highest three classes of Suhrawardi's theosophists.

In this regard, al Ghazzali (1964:39) has strongly hinted at a hadith, "There is a science like the hidden pearl that is not revealed except by those who know God; whatever they talk about will be denied by people who do not know God, and they have to keep strictly all of the secrets although many people suffer misunderstandings." This narration is to strengthen his previous statement, "All of secrets should not be revealed, and every truth could not be exposed, but the freeman's chest is the secret's grave."

Perhaps the last works of Theoretical Mysticism in the Islamic tradition are represented by Mishbāh al-Hidāyah Ila al-Khilāfah Wa al-Wilāyah, as the result of mystical human experiences. In the epilogue book, Imam Khomeini (1993: 90) wrote, "Be careful, O spiritual companions, and once again beware, may God help you in the world and your afterlife, with giving secrets away to people who don't deserve them [...] for the knowledge of inner shari'a, of divine laws and of God's secrets must be saved from strangers effort and their look."

One of Islamic Mysticism doctrines is "to disclose divine secrets is idolatry" (Khomeini 1996: 193), that is, revealing a mystically experienced reality 
collides in general with people's faith and reason to such an extent that eventually it makes them sceptic. Indeed, there are many reasons why mystics have been holding firmly to the doctrine of covering and secrecy (sitr wa kitmān). In addition to social conditions that often make them no different from unbelievers, this doctrine itself is an implementation of the prophetic traditions, an implication of the principle of justice (' $a d l$ ) in order to get along with others according to each of their capacities, the principle of moderation (itidall) as a way of preserving self-control, and the principle of love for creatures as a genuine commitment to the innate love of God. All that is what they have been reluctantly encouraging themselves to exclusively survive a society as an elite group of inclusive Muslim scholars.

Although the rule of "to love something is to love its image" defines the Muslim mystics' decision to restrict social and intellectual interaction with anyone who could potentially misunderstand or feel uncomfortable toward patterns of their own expression of the experienced truths, but it does not make them so exclusive and completely alien among people, since the principle of justice also motivates himself also to be able at the same time to expose some of the truths according to everybody's capacity. There are a lot of criteria of eligibility proposed by Suhrawardi (1994: I/194) to examine especially his theosophical doctrines, as he calls readers to study carefully Hikmat al-Ishräq on the promise that they have been already well versed in the theoretical sciences, to be well practised in spiritual training, and to thoroughly remove themselves from the mortal life.

\section{Extremism}

Throughout the history of Islamic tradition and Muslim scholars, it has been common to get so many various claims and declarations of the absolute truth in an effort to approach or even reach the Truth, but it is certain that there is no 'hotter' and more powerful claim than mystics' assertion upon the Truth. The "hotter and more powerful" syntagm is often considered as a sign of extremism emerging from the Muslim mystics who eagerly attempt to convince their success in knowing the truth, that is, there is no essence except being; there is no being except the one; and there is no one except God, and nobody, of course, knows God except the mystics. Here are the clear signals of exclusivity and extremism sharpening their deep pessimism about the various achievements of others, either via text or reason.

Describing the truth itself, Muslim mystics say that experienced truth is unreasonable, especially if they degraded it by text. Mystical experiences of the truth could not be designed entirely by conceptualization size or developed through description. There is a consensus among Muslim mystics that 
their own mystical experience is a realm beyond that of reason (t $\underline{t} a w r$ wara tawr al 'aql) and, moreover, they are actually able to gain the truth which is beyond the domain of reason. Thus, in their metaphor, the lack of language sharpness is often neutralized by the phrase "because of merely narrow oesophagus".

The above issues have already shown that neither mystics' exclusivity nor their extremism are solely triggered by a deficit of the capacity of others, but also due to the limitations, debilities, and shortcomings as the natural and innate realities of human being they faced frequently throughout the presentation and complained about them in their own works as well. That is why many mystics and observers have been regarding the paradoxical expression (shathah) as an inevitable and permissible phenomenon (see: Lahiji 1995: 297, Otto 2003: 45, Stace 1960: 254). A variety of statements such as "Glory be to me! How great my standing!" from Abu Yazid Bastami or "I am God" from Hallaj are prevalent examples that conspicuously represent a vast array of mystical paradoxes, many of which have left traces of extremism, and up to now have been horrendously provoking sensational reactions and cynical views of the public, and have even been tarnishing the mystics' sincerity in reasoning and talking about the Truth. Whether we like it or not, the negative impressions of extremism and paradox patterns have been a reality of Islamic sciences history that completely fill the empty spaces encircling the exclusivity and inadvertently prevent the advent of mystical truths among intellectual activities and common people's life.

On the other hand, the account above is by itself a convenient way to identify the prime objectives. Generally and roughly speaking, there were two methods used by mystics to reduce as minimally as possible the adverse impacts of natural limitations and shortcomings mentioned earlier: firstly, conceptualization and secondly, presentation. What is meant by 'conceptualization' here is an act of unravelling and understanding the experienced truth, while presentation is to interpret the understandings and grasps of the truth into language system. Thus, the conceptualization and presentation, in my opinion, are just two distinguishable patterns of human experience.

\section{Logical Forms}

Conceptualization is a reason mode of interpreting and explaining an experience of the Truth through concepts and propositions in the forms of definition and inference. From the very beginning it will deal directly with Logic, particularly Aristotelian logic, in Islamic Theoretical Mysticism. Related to the unity of being as a theoretically basic principle of Islamic Mysticism, it is grossly excessive to consider Ibn Arabi as the founder, yet he 
should be recognized in a high position as a Muslim mystic who successfully innovated an authentic formulation of the principle and analyzed a diverse range of its implications about monotheism (God), manifestation (creatures), and monotheist (perfect man).

Ibn Arabi's tremendously determined effort to conceptually extract the unity of being and its implications is astonishingly accomplished within logical inference and figures, ranging from definition and proposition to syllogism, and incessantly burgeoned in such a way that his own works just played the pioneering role in establishing a novel system of Islamic Theoretical Mysticism based on the intuition (shuhüd) and knowledge by present ( 'ilm hudhūrì), while the cohesive construction of the system was performed wholly as a disciplinary science through the great disciples and followers of his (see: Yazdanpanah 2009: 34).

It may be debatable whether Logic vastly engrossed Ibn Arabi all the way to its formal and material formulas, but it is not dubious whether his own disciples attempted to generate thoroughly the system of Theoretical Mysticism adjusting all their explanatory elements as a coherent whole and guaranteeing them against any fallacy and contradiction refuted absolutely by Logic. As conscientious commentators, they made every effort to interpret cautiously Ibn Arabi's phrases and properly justify all his accounts and those efforts seemed apparently like paradoxical and self-contradictory statements in a way that does not collide with the principles of Logic such as the Law of Contradiction.

Sadruddin Qunawi, Muayyiduddin Jandi, Saeduddin Farghani, Mulla Abdurrazzaq Kashani, Mahmud ibn Dawud Qaisari, Sayyid Haidar Amuli, Sainuddin Turkah, Muhammad ibn Hamzah Fanari, Mulla Abdurrahman Jami, Sadr al Muta'allihin, Mirza Muhammad Ali Shahabadi, and Muhammad Hossein Tabatabaei are some of the Muslim mystics who have showed their dedication to teaching the doctrines of Theoretical Mysticism within the framework of logical forms (Shirazi 1981: II/315). They always do their best to preserve the coherence as an inevitably prime basis in order to, at least, shrink from any potential threat of contradiction and inconsistency within the units of Theoretical Mysticism.

\section{Philosophical and Theological Terms}

There are thereby ample opportunities outside the circles of mystics, notably the philosophers, to be actively encompassed in analyzing, explaining and demonstrating any theoretical proposition of Islamic Mysticism, even if they do not at all have any mystical experience of the Truth. These opportunities get more open when in very fact the disciples and followers of school 
of the unity of being, even Ibn Arabi himself, have made many propositions, premises, and conclusions relying on technical terms which are authentically produced by Muslim philosophers and theologians in an effort to present the teachings of Theoretical Mysticism, especially as long as it relates to the ontological and epistemological problems.

Apart from the fact that mystical writings were characterized by metaphor and simile, most of the disciples and followers of Ibn Arabi's school have just had the experience of doing Islamic philosophy, e.i. Peripateticism, Illuminism, or Transcendent Philosophy (Hikmah Muta'aliyah), even that of Plotinus, Ikhwan al-Safa and Ismailiya (Afifi 2002: 7). For example, in explaining the main subject of Theoretical Mysticism or in withdrawing the unity of being from the list of paradoxes or contradictions, the Muslim mystics have been using the term 'ibāriyyât (perspectives) that is commonly ap= plicable in philosophy, particularly in observing the quiddity (mähiyat) (see: Dinani 1987: II/612-614).

Consequenly, Theoretical Mysticism until now has not only provided a dialectical domain to Philosophy, but this Islamic science has also accommodated the involvement of non-mystic researchers. Among the highly esteemed names mentioned earlier, Fanari is endorsed just as an observer whose work, Mishbāh al-Uns, has been admired and so far respected as a handbook in the high level of Theoretical Mysticism after Fusüs al-Hikam (see: Yazdanpanah 2009: 50). This mutual dialogue as well as its positive impacts will remain vibrant when Muslim mystics place the requirement onto students/scholars to equip themselves with the mastery of theoretical sciences first. In addition to the account quoted from Suhrawardi, Sainuddin Turkah has insisted on Logic functions and speculative reasoning as part of the criteria that properly identify a true knowledge as well as the false ones (Turkah 1981: 270). Instead, conceptualization and presentation of mystical experience divested of any paradoxical impression and contradiction areas are actually the indication of mystics' sincerity with regard to tariqa and haqiqa (Khomeini 1999: 622).

In the Islamic tradition, Theoretical Mysticism has been maintained basically as a theory of reality unveiling (mukāsyafah) on the top of intuitively innate knowledge experienced by a mystic throughout tariqa, that is, annihilation $(f a n \vec{a})$ and witnessing of the profound reality of the unity of being. Annihilation is thus the end of Practical Mysticism as well as the infancy of Theoretical Mysticism; it is the central point that connects these two fields in which a mystic has to go incessantly across the stages of tariqa so that he 
eventually gains a variety of mystical experiences on the possibly final level of the reality and only then he could formulate them in the conceptual perception. But on the other hand, it would not be wrong if the term 'formulate' used here is also defined as a process of degrading mystical experience of reality to the conceptualization ground.

Thus, all kinds of description, definition, inference and conceptual presentation, for the mystics themselves, are just an attempt to stretch the essence of reality from the terrain and to blur the clear vision of the object. Their assertion that witnessing the reality lies beyond the realm of reason and that the mystical experience of the reality is not adequately represented in language, precisely becomes a sufficient reference for some people to, in the first place, declare that mysticism has no logic other than its own logic or what is also called superlogic (Otto 2003: 45), and secondly, judge the paradoxical expressions as a concrete reference of superlogic based on the contradiction.

The Muslim mystics have been deeply aware of the problem of the degradation of truth and the contradiction between interpretations. Introduced as the largest veil (hijäb akbar), conceptualization of the truth is actually a worst option given that the love of creatures is just a part of the love of God. But as for contradiction, it hasn't just been a consensus among Muslim mystics. There is no doubt that, at least, the followers of Ibn Arabi's school couldn't be satisfied that their own mystical doctrines have allegedly produced all this time a variety of contradictions and evoke public's cynical opinions against Mysticism. The successfully tremendous effort of theirs in order to construct a theoretical system of Mysticism and to design it into the whole discipline is in fact an evident indication of their consistency upon Logic as well as their way to accommodate Philosophy.

This glorious attempts made by Muslim mystics are not, of course, detrimental to the affirmation of wholeness mentioned before. However, unveiling and experiencing reality lay beyond the scope of reason and interpretation. Perhaps contradictory or paradoxical impressions were already set to be commonplace among the general public. It is unlike reductionism, as has been noted earlier, whose chiefly theoretical efforts to overcome the risk that a significant reduction in space is exclusivity. Still, there have been undeniably major contributions that emerged from Theoretical Mysticism in enriching the tradition of religious and rational thoughts in varied disciplines such as Exegesis, Philosophy, Epistemology and Theology.

It seems rather pompous that the practical function of Theoretical Mysticism is considered as a way to conclude deductively a jurisprudential law (Hashimian 2000: 54) or to seize an opportunity to lead a management system. Indeed, there is a number of normative values such as justice, moder- 
ation, straightness, and love developed in this discipline, but these are no more than moral responsibilities and ethical consciousness that enhance a mystic's vigilance to interpret realities and to represent truths unveiled mystically before. To the best of the assertion of Muslim mystics through their theoretical works, the practical function could be, at least, expected as a derivative of interpreting mystical experiences and formulating them into a theoretical science, that is, providing assistance to mystics in order to understand tariqa stages before appropriately reaching the Reality, to clarify the paradoxes, to avert the contradictory expressions, and to motivate others to be eagerly involved in the part of mystical experience.

Maintaining a long-standing commitment to the function and the objective of interpretation mentioned above, an effort to expand the answer to the question for what is Theoretical Mysticism made is required not only for the sake of intellectual interests and enrichment of knowledge about God, universe, and human being, but also it has to be considered how to intrigue others in such a way that they get keen to directly sit for spiritual training and to consequently witness reality, albeit just enough to rudimentary stage of it according to the common people's capacity and the level of ordinary life.

At the same time, we are also required to expand the answer to the question: for whom is Theoretical Mysticism made. What can be inferred from the above description, Muslim mystics have formulated Mysticism as a discipline as they realized that this science could not be accessible to all people. Although Ibn Arabi declared in the introduction of Fusus al-Hikam that the Prophet Muhammad had entrusted onto him to publish the book to the public (Ibn Arabi, 2002: 47), but throughout the book as a 'translation' of his own mystical experiences, he actually used a style of language loaded with a large number of metaphors, similes, and extremely technical terms. Hence, mystical interpretation and the presentation could only be accessed in general by those who had already been well practised in dealing with metaphysical terms (Khomeini 1993: 90). The typical accentuation of repetitively immense alarm emerged from preface as well as closing entry of mystics' works reinforced the impression of exclusivity.

To expand the answer here is the first attempt to approximate the possibility of opening up an access point to the unity of being and to provide as wide opportunities as possible to be optimized by people as much as possible. In this respect, it is expected that in the contemporary world, the amount of desperate need and optimism could reasonably be observed, so that answers could be given to questions such as how the mystical experience and innate knowledge in Mysticism can foster the love of science and establish a spiritual basis that would be to the benefit of the intellectual, moral and social life, whether Sufism could be useful to deal with problems of today's 
humanity, how important and relevant theoretical Islamic Mysticism is to the contemporary world, and how the establishment of Islamic Mysticism can be explained in non-technical terms.

\section{The Method of Understanding}

The main problem that Muslim mystics faced in an effort to conceptualize their own divine experiences is to abandon the traps of objectification and reification. As Afifi (1937: 572) defined Philosophical Sufism or Theoretical Mysticism as metaphysical principles or a set of philosophical theories formulated by a mystic the moment his experience of annihilation $(f a n \bar{a})$ has already come off, in order to interpret or argue for personally experienced realities. In this objective state and in an effort to interpret, a mystic's position hardly ever differs from an observer's who does not have any divine experience, even if they both are in the same position along interpretation and conceptualization in which they have equally regarded the unveiled reality as an object (Copleston 2002: 198). The act of objectification is to install a wall of demarcation between the experience as an object and the observer as a subject. Interpretation, thus, is to eject the subject from its realm of unveiling the reality so that the subject itself falls behind that of the object.

The objectification that establishes the formula of subject-object is a normal option inevitably looked at when conceptualizing and formulating science as a whole discipline. That is the way Heidegger regarded it - as a fundamental problem of philosophy and theoretical system whatsoever. Regardless of his widespread criticism of the system of Western philosophy based on earlier dualism, he just represented Dasein to gain a good grasp of the existence. At least, the concept of Dasein as the core as well as the vehicle of approach to the existence can also be a useful contribution as it deserves a subject role in the understanding process without being correlated with the object and, for that reason, Dasein established himself as an original. (Mulhall 2005: 37). In this respect, Heidegger's hermeneutics, therefore, require that the subject of text (reality) should be profoundly engaged in all aspects encircling the text so that he himself becomes a part of it.

When the hermeneutical element above is properly used in the method of understanding, the possibility of constructing an alternative paradigm should be explored through three criteria: firstly, the subject in common people level enjoys the capacity to experience and to understand the text (reality and divine realm); secondly, the text is available to all those in the lowest level of the subject's capacity; and thirdly, the text is accessible to everyone. The tremendous possibility thereby expected is that the dualism 
and the demarcation would evaporate so that everybody remains in the subjective realm of unveiling divine reality, albeit at the elementary level.

\section{Knowing the Self}

To accommodate the elementary level of unveiling the Truth and to open up the profuse potential to escape over the trap of exclusivity, an alternative paradigm would be initiated but not from the point where Theoretical Mysticism starts, even though both would eventually culminate in the same end. In other words, instead of moving to Theoretical Mysticism and logical interpretation only, a Muslim mystic may persuade others to realize the experience of the Truth by taking a step backwards, that is, by starting a mystical path without having to become a formal student (Nayshaburi 1997: 142), or to get busy encountering technically varied terms.

In the Islamic tradition, the history of Sufism is usually traced back to an ascetic lifestyle of a group of early Muslims whose ethos was vastly supplied by the verses of the Holy Qur'an and the Prophetic traditions so that a few leading figures appeared among them like Hasan Basri, Ibrahim ibn Adham Balkhi, Fudhail ibn Iyadh and Rabi'a al-Adawiyah. Asceticism, as Afifi (1937: 573) underlined, constituted the first stages of the whole evolution of Sufism in the third century of Hijra, that is, people definitively distinguished between ascetic and mystic. In the sense of Sufism, asceticism is a way to purify the self until it terminates at witnessing its nothingness. Their primary focus is on the soul and ownself.

"O ye who believe! Take care of ownselves! He who erreth cannot injure you if ye are rightly guided" (Qur'an 5: 105).

In addition to love, the principle of knowing the self (ma'rifat al-nafs) is entirely recognized as an axiom of Sufism and a consensus among Muslim mystics. This highly firm position is apt to put the principle as the main path leading to tariqa, a sound basis for achieving haqiqa and, at the same time, the definite answer to the question where the construction of the paradigm would start.

In the century that marked the infancy of Islamic Theoretical Mysticism, the principle of knowing the self often accompanied Ibn Arabi's writings in order to account for a large number of issues of Theoretical Mysticism. Following his considerable emphasis, the Muslim mystics offered a detailed analysis on various meanings of knowing the self alongside love. In philosophical terms, knowing the self and love are both truly realized as knowledge by presence (hudhūri); someone knows an object as well as its quality 
by its own existence, not through concepts. Regardless of any meaning of knowing the self and love, we have considered it as the strictly accurate, as it appeared that there was a relative lack of further research into the relation between the two at great length.

According to Ibn Arabi, unveiling and witnessing the reality, in addition to the appearance of the human esoteric substance, is an impact of manifestation of the Truth's in the believer's heart, and an effect of the essential desire (tham' thabì $\vec{\imath}$ ). Therefore, the base of the mystical experience and witnessing the Truth is an inherent tendency residing in human nature to strongly encourage somebody to encounter the Truth (Ibn Arabi: IV/59). To argue for the existence of the inherent tendency, Ibn Arabi initially refers to the hadith: "Allah created Adam based on His form", and then classifies man into main categories: animal man (insān hayawān) and caliph man (insān khalifah). Someone could realize his own self free from the identity of animal when he has reached the divine degree, that is, he knows himself as the Truth's form by presence, unveiling and witnessing himself. By virtue of the divine form, he would thoroughly deserve to hold the promise of God to assume the identity of caliph or imàm (ibid.).

Ibn Arabi elsewhere in his works also explained the origin of the promise of God, which the Holy Qur'an introduced as a pure religion (din khälis) (Qur'an 39:3). The menaing of "religion" here is identical to that of mere obedience (inqiyäd). Caliph human, therefore, is the concrete personification of religion and absolute obedience so that he does not break free from the evil whisperings, but also from motives like fear of hell or hope for heaven. $\mathrm{He}$ then traces the origins of the divine promise to $d z a r r$, a realm of the pre-creation of man, in a way that he arrives at the level of fitrah when someone is born. Fitrah, in fact, is the pure promise that has underlain the creation of man in the state of sincere, pure and sacred nature (Ibn Arabi: II/615). Eventually, Ibn Arabi concluded that fitrah is merely the essence of human soul created by God in perfect condition as an intelligent and believing slave of God, "That's on the basis of the nature that God created man." (ibid.: 677).

"Fitrah [framed] of Allah, in which He hath created man. There is no altering [the laws of] Allah's creation. That is the right religion, but most men know nothing" (Qur'an 30: 30).

Indeed, the account of knowing the self proposed by Ibn Arabi to investigate its origins to fitrah, in my submission, could be explored further. It looks that he hadn't thus far explained why and how fitrah and man's soul had faith in the oneness of God and acknowledged His divinity. In this respect, he hinted that there are some people whose fitrah remains intact, un- 
contaminated, original and authentic just as they were created from the early time (Ibn Arabi: IV/60). But this report still leaves a further examination of what relation could be explained between the authenticity of fitrah and witnessing the Truth. However, it is just an ample effort to place the principle of knowing the self as the main path and fitrah as the base for a new paradigm construction (see: Khomeini 2003: 164, 1999: 530).

Knowing the self, as far as compared with the three hermeneutical criteria of the method of understanding, may be inadequate, because this principle, at least, according to the second criterion, does not provide a text in the level of lowest capacity of common people. This is evidenced by many different interpretations offered by the circles of Muslim mystics and scholars on the contents of knowing the self (see: Ibn Arabi 2002: 81). But in terms of fitrah, this human essence accommodated the three criteria at once, as it would appear in further details of its laws. Meanwhile, the relation between fitrah and knowing the Truth could be analyzed in an effort to explore the substance of fitrah itself. In the following accounts it will emerge how fitrah accommodated love as wide as possible on the number of cognitive and motivational functions.

\section{Fitrah and Love}

What would be discussed in terms of fitrah here is of course not similar to that of Allamah Tabatabaei's account for proving the unity of being as the essence witnessed through a perfect and simple (sädzij) vision based on man's nature, hence in his explanation he uses a range of philosophical concepts and technical terms. The earlier word "simple" has to be meant in the context of Formal Logic, that is, the doctrine of the unity of being constitutes an innate proposition (qadhāya fitriyyah) that was so clear and self-evident (badihi) in such a manner that everyone would assert its truth unhesitatingly and straightforwardly (Tabatabaei 1995: 21-22). But the use of fitrah for the alternative paradigm here is exactly common and popular meaning among the general public, even the grassroots level. This ordinary meaning is actually a pure term of the Holy Qur'an adapted from the verse beneath:

"So set straightly thy face [O Muhammad] for Allah's religion; [keep on] fitrah [framed] of Allah, in which He hath created man. There is no altering [the laws of] Allah's creation. That is the right religion, but most men know nothing" (Qur'an 30: 30).

Fitrah in this verse is introduced literally as a nature by which man's whole existence was based on. In its lexical sense, it refers to tearing or making 
something that was not there before so that the creation here means tearing the veil of man's absence. Hence the man's reason d'être is fitrah; because of fitrah, all human beings was created and born; because of it, each of them is growing, surviving and striving for eternal life. Everybody's nature is solely defined by fitrah. In the following clause of the verse, fitrah is described as the essence that can never be changed, as a substance that belongs to everyone without any difference at all, a light that always flames, remains pure and authentic since the beginning of one's birth. In a popular hadith, "Every baby was born on the basis of fitrah." This means that man will never ever either lose or make fitrah dormant; only by burying and covering fitrah with the veils of sins or wrongdoings could man suffer a lack of being sensitized to their alarming frequencies. Explaining the philosophy of Prophethood, Ali ibn Abi Talib (2001: 30) stressed, "That is to require man to keep a promise of His fitrah, and to remain him of His forgotten grace."

The light of fitrah could only be strengthened or weakened. For this reason, someone wouldn't be motivated to look for fitrah, but they were tempted to repent and listen for it. The absence of fitrah means only that a person is lying in a state of neglect and unconsciousness (ghaflah) and in need of being reminded (dhikr) in order to begin to regain consciousness (yaqzdah) whipped up by the will and determination ('azm) so that he restores his own authenticity. Hence this determination is sometimes appreciated as a substance of human beings that distinguishes themselves from others (Khomeini 2003: 7). Determination is not something that is earned, but it was embedded in the self as a part of the manifestation of fitrah and, as Avicenna (1996: III/384) stressed, the first of mystical stations.

It is here apt to observe how to realize fitrah, to listen to its echoes and to begin to be authentic. The Holy Qur'an briefly but very clearly stated:

"Oh, but man is a telling witness against himself, although he tender his excuses" (Qur'an 75: 14-15).

"Telling witness" in the above the verse refers to the use of the Arabic word "basirah" that is indistinguishably identical to what we can call "heart's eye". In comparison to head's eye functioning as eyewitness, heart's eye is also a sharply inherent witness that uninterruptedly monitors what someone thinks and acts, automatically shows either to the right way or wrong one, and never ever tells a lie or contributes a mendacious input, although he has been trying to make himself comfortable with overwhelming reason and wave after wave of fresh justification. Furthermore, in this verse, heart's eye was put in the opposite to excuses (ma'a dzir). This is actually to confirm the status of heart's eye as a source of the authentic evidence lowering any value 
of the evidence against it to not more than an excuse. The Muslim mystics, therefore, called it a power in the heart shining with sacred light that leads somebody to unveil realities and witness all their intrinsic dimensions. That person who has gained the holy heart's eye properly deserves the perfect self and pure soul enjoying the divine vision with the guidance of the Truth (Kashani 1991: 18).

"And a soul and Him Who perfected it, and inspired it [with conscience of] what is wrong for it and [what is] right for it"

(Qur'an 91: 7-8).

No matter how his gravest sin or slightest mistake was made, it is absolutely certain that he would feel a kind of inconvenience engulfing his soul. In some verses of the Holy Qur'an, it is often repeated how the essential character of the human soul was described: he would remember God and return to Him soon after a trouble came to him (see: Qur'an 10: 12, 29: 65, 30: 33, 39: 8). He would return to God not through reason and intellect, but thanks to the responsiveness of the heart. This is actually the lively text of fitrah that is available and affordable even to common people as the subject. In some of Muslim mystics' works (see: Shahabadi 2001: 133, Khomeini 1993: 40, Tabatabaei 1995: 24), fitrah is, therefore, called the self's book (kitāb al-dzāt), while the inner consciousness and insight emerging from it roughly correspond to 'reading' (qira'ah):

"Read thy book, thyself sufficeth as reckoner against thee this day" (Qur'an 17: 14).

The frequency of fitrah would easily dawn on someone when they have already committed, for the first time, even a minor breach of the virtue values: by fitrah they witnessed themselves loving the virtue, the justice, and the beauty so that they feel sorry and ashamed of what they have done. It is just an extravagant claim that this common experience of realization and witness is identically aligned with the mystical experience indeed. Having said that, however, the latter can even be approached by the former. Based on the fitrah's properties such as equality, being unchangeable, and authenticity, this shape of approach here does not mean that common people lie on a high level of spirituality that constitutes the mystics' base for gaining the mystical experience and witnessing the Truth.

Pharaoh's story is a properly relevant reference to the approach of fitrah. He was a prominent instance of the most arrogant man when he made a most gigantic claim of his own ego to stand up to Almighty God (Qur'an 28: 
38, 79: 24), but he came finally back to God and declared his faith in Him through the light of fitrah. Who knows whether or not he really encountered God before sinking, but somebody in the same position would witness, as Imam Ja'far al-Sadiq described (Saduq, 1998: 4-5), the absolute dependence of his whole existence upon Almighty God:

"And We brought the Children of Israel across the sea, and Pharaoh with his hosts pursued them in rebellion and transgression, till, when the [fate of] drowning overtook him, he exclaimed: 'I believe that there is no Allah save Him in Whom the Children of Israel believe, and I am of those who surrender [unto Him].'What! Now! When hitherto thou hast rebelled and been of the wrong-doers (Qur'an 10: 90-91).

Only the essentially crucial role here is to try to be absent from such a condition that isolate all the options but death. That is to say, how do Muslim mystics and observers of Theoretical Mysticism cultivate fitrah, maintain their authenticity, and assist common people in gaining the mystical experience and encountering the Absolute by full awareness, free choice, and under normal conditions? In this respect, some of them present an adventure story of the Prophet Ibrahim seeking the Absolute (Qur'an 6: 76-79). Beginning by gradually identifying stars, moon, sun, or anything that man's imagination can consider as the most beautiful and the absolutely perfect, the Prophet Ibrahim critically refused all of them through a short argument, "I don't love any of the imperfect ones." So, whatever we suppose has a slight possibility of being lost or less, however beautiful and perfect it is, would not be the main target of love:

"Thus did We show Ibrahim the kingdom of the heavens and the earth that he might be of those possessing certainty. When the night grew dark upon him he beheld a star, he said, 'This is my Lord.' But when it set, he said, 'I love not things that set.' And when he saw the moon uprising, he exclaimed, 'This is my Lord.' But when it set, he said, 'Unless my Lord guide me, I surely shall become one of the folk who are astray.' And when he saw the sun uprising, he cried, 'This is my Lord! This is greater!' And when it set, he exclaimed, 'O my people! Lo! I am free from all that ye associate [with Him]. Lo! I have turned my face toward Him Who created the heavens and the earth, as one by nature upright, and I am not of the idolaters"' (Qur'an 6: 75-79).

The Prophet Ibrahim's argument is no more than love within heart, not speculations in mind, and only then it ultimately encounters the Absolute 
Being. Even though Sadr al-Muta'allihin (Shirazi 1981: IV/43-44) interpreted the story in the philosophical frame of the demonstration of motion (burhān al-harakah) for the existence of God, it is just relevant to the reading of love. Love does not deal with the intellect so that it couldn't be explained by logical definition and inference. Love solely belongs to fitrah and heart's eye that would lead man to where he should move and to whom he should encounter.

In short, love is the prime quality of fitrah, namely, the nature of love of the perfect. Human beings have a lot of experience in loving many things, but fitrah would not stop loving and finding the perfect realities. Based on fitrah, whenever someone has freshly been satisfied with the latest success in gaining the perfect, he would stop loving others, but he will be provoked by even the purely hypothetical case that there is a most perfect being or, at least, more perfect than the latest one. As the Prophet Ibrahim argued, fitrah perpetually lead human beings to love the perfect ones. He just finally found the happiness to see God as the Absolute and Ultimate perfection. Eventually, fitrah wants annihilation ( $($ ann $\vec{a})$, melts away in the Absolute Reality. Therefore, achieving annihilation is gaining the degree of wilayyh as an ultimate status of witnessing the Truth. The degree of wilayah, thus, is just an inevitable consequence of fitrah (Khomeini 1998: 100).

In other words, the unity of being can be approached through fitrah of love of the Absolute Reality. Supposing impossibly that there is a reality that has a primacy over the Absolute Perfect, fitrah is going to abandon Him and begin to pursue it. This approach of fitrah did not merely explain what man would know and meet, but also how he should come to know and to see the Absolute. Hence, fitrah functions, in addition to its status as a basis to knowing (epistemological role), as a basic motivation (ethical role) for encountering the Absolute.

The fitrah account of mystical experience and witness could mark the beginning of an attempt to grasp hadith qudsi that often constitutes the axis of Islamic Mysticism studies, namely, the narration of treasure; God says, "I was a hidden treasure, then I love to be known, hence I have created things so that I would be known." The term "love" is used as it literally refers to the Arabic word ahbabtu. Of God's love, universe is created, and by fitrah's love, God is reached. In the Theoretical Mysticism, Muslim mystics call this cycle the motion of love (harakah hubbiyyah) along two curves (qawsain): descending one (nuzūli ) and ascending one (su'üdì).

In the paradigm of fitrah, the unity of being constitutes an affordable level of witnessing the Truth as well as an available foundation installed equally in all human beings so that common people are also able to cultivate the Truth-unveiling mystical experience and to materialize its moral implications 
throughout the dimensions of life so ordinary that the threat of exclusiveness and extremism from a few Muslim mystics could be neutralized significantly. In the social and personal implementation, to be sensitive to esoteric alarm, to be responsive to the directives of heart's eye, and to be aware of the sense of responsibility toward any breach of laws like: injustice, discrimination, oppression, corruption, insincerity, hypocrite, and any kind of immoderation are human, religious and mystical-fitrah values that should be developed and fostered in maintaining the motivation to move and rip the concealing veils off in order to encounter and witness the Truth.

\section{Dialectical and Interrogative Language}

The language of Logic and demonstration is the arrangement of propositions so as to present a new knowledge. To produce conclusion in the syllogistic frames, the logic language doesn't use any forms other than declarative ones. These language forms may also work in favour of uncovering the contents of fitrah. But before considering this function, it was apt to observe the language used in interpreting the Prophet Ibrahim's experience of seeking and encountering God. Throughout the story, as the Holy Qur'an recorded, there was just a gradual ascent guided by a constantly dialectical pattern. This dialectics was carried out by fitrah since the beginning of finding the Absolute.

This dialectical method shows that the language of fitrah does not hamper the dialectical ascent and pace. Adopting Neo-Wittgensteinian terms, fitrah is a basically typical experience of the forms of life that has implications for the models of language and the patterns of presentation following the rules of a particular game. The languages of intuition and the fitrah reading are not exactly similar to declarative statements, but they are properly framed by questions and interrogative sentences that drive the dialectic cycle.

Because truths were already embedded in the self, all the questions based on fitrah are not merely proposed and developed to acquire the knowledge, but each of them is put forward in order to discover the hidden truth that God has installed in the recesses of the self. The interrogation by disapproval or self-critical question (istifhām istinkārì) would only generate the vibrant dialectics if someone placed the sincerity as a basis of commitment, for what he has been dealing with is fitrah and intuitive consciousness that are characterized as pure and authentic essence. Fitrah by itself would lead the human innate love to unveiling the Truth and encountering the Absolute through the dialectical spiral with the genuine commitment to being honest, sincere and straightforward.

Imam Ja'far al-Sadiq narrated that someone asked him "Is there any argument for the existence of God? Guide me who has been confused by deba- 
ters!” Imam Ja'far began to interrogate him, “Have you ever been on a ship?" "Yes", he replied. Imam said, "Have you ever seen a ship rupture and there was no rescuer or even a swimmer who could save you, while you ownself couldn't swim?" "Yes", he replied. Imam asked him again, "In such a situation, whom would you lay hope on?" He said, "I would lay entice hope on the Omnipotent Being and the Merciful Savior when all the bonds dispersed and the causes lain dormant" (Saduq 1977: 231). In this regard, Imam al-Sadiq in fact was merely a representative of the interrogative language of fitrah that has helped him uncover actively by himself the innate truth by dialectical pattern. This method is actually also used in many verses of the Holy Qur'an to touch the authenticity of fitrah (see: Qur'an 14: 10, 6: 14, 52: 35).

Besides the strong connection between the principle of knowing the self and teaching of Delphi "Gnothi seauton!" engraved on the temple of Oracle, the dialectical presentation can also be traced in ancient Greek tradition to Socrates (Durrant 1993: 74). Most of his teachings was immortalized by Plato in the forms of dialogue and interrogation. The epistemological doctrine of anamnesis evidently strengthened the Socrates' dialectics. According to Muthahhari (1991: I/235), he applied his own method in practice throughout the learning process due to his belief in the values of truth contained inherently in the human soul. Socrates midwife just helped a fetus move slowly in the natural path and come out of the womb glowing with health.

\section{Epilogue}

The above account of fitrah, love and language has taken place in the context of the philosophy of Mysticism or Metamysticism, that is, observation of mystical experience and fitrah outside of their scopes, and this observation obviously parallels what was previously called objectification, since it is just a sole way to introduce the paradigm of fitrah to be considered as a nucleus as well as a vehicle of witnessing the Truth, despite the fact that common people could gain an experience of the Truth at a primitive and elementary level so that it is more accessible and extremely convenient for all of them. If we readily admit that mysticism is the inevitability of human life, then as Bacon said, there is no more evenly divine gift spread over all of human beings than love and fitrah.

Perhaps what was discussed on behalf of the paradigm of fitrah does not describe more than the bare bones of the novel approach offered by a number of the most recent Muslim mystics, especially, Muhammad Husain Tabatabaei and Muhammad Ali Shahabadi, in most of their own philosophical, mystical and exegesis works. The paradigm of fitrah itself was initiated by the term "irfan fitri" (mysticism based on man's divine nature) which is, 
for the first time, abundantly introduced by Shahabadi's best disciple, Ayatollah Ruhollah Khomeini, in one of his mystical letters (Khomeini 2003: 97).

Apart from love, Muslim mystics also identified an impressive array of basic characteristics of fitrah such as aversion to imperfection, egocentrism ( $\underline{h} u b b$ al-dzāt), hedonism (thalab al-rāhah), and authoritarianism (istibdād al-ra'y) (Shahabadi 2001: 127), as they evolved each of these classic characteristics through a variety of classification. Each of the characteristics has the sufficient potential to reconstruct a set of Theoretical Mysticism issues relating to God, the universe and the human being, and it is also highly effective on examining the purity of tariqa and on maintaining the real commitment to sharia. For some scholars of Metamysticism, the nature of egocentrism, in the positive sense, has begun laying a foundation for establishing a new approach to the Philosophy of Ethics (see: Shirvani 2003: 36-42). There are, of course, plenty of other far-reaching consequences to developing moral values and lively motivations based on irfan fithri so that these would yield a great advantage for the management, jurisprudence, and other practical fields.

From the very beginning of the paper, there has been a consistency afforded as much as possible just for the sake of exploring the potentials, especially originated from the heritage of the latest Muslim mystics. To theoretically introduce the experience of the unity of being through an approach of innate love has been prioritized here as an initial pace to unearth the real possibility, if not to say the compelling evidence of founding a new paradigm based on fitrah through the efforts of extracting mystics' theoretical teachings from the scope of exclusiveness in such a way that they are accessible to inclusive human beings in two phases: going back into the main line, namely, the principle of knowing the self, and secondly, probing so deep into the nucleus of this principle in order to reach fitrah as an inexhaustibly rich source of human perfection so as to take the first step, to convoy the spiritual itinerary and to finally have the divine vision of the Truth.

In this respect, the paradigm of fitrah was also actually apt to explain how a wayfarer (sālik) encounters the Truth. However, it is necessary to insist that issues in Islamic theoretical mysticism could be replaced by the paradigm. It seems that the paradigm of fitrah is quite valuable when it bypasses the path to erode away the wide gap between Theoretical Mysticism and daily life. In line with this, both (the paradigm of fitrah and theoretical mysticism) play complementary roles in various spheres of human society and history.

Received: August 30 ${ }^{\text {th }}, 2013$

Accepted: September $28^{\text {th }}, 2013$ 


\section{References}

Ali ibn Abi Talib (2001), Nahj al-Baläghah, Subhi Saleh (ed.), Qom, Mu'assasah Dar al-Hijrah.

Afifi, Abul-Ala (1937), “al-Tasawwuf al-Falsafi fi al-Islām”, al-Risālah 194: 570-575.

Avicenna (1996), al-Ishārāt wa al-Tanbìhāt, Qom, Nashr al-Balaghah.

Copleston, Frederick (2002), Religion and the One: Philosophers East and West, London - New York, Continuum.

Dinani, Ghulamhusain Ibrahimi (1987), Kulli-e Falsafì dar Falsafeh-e Islām, Tehran, Hikmat.

Durant, Will (1993), The Story of Philosophy, Abbas Doryab (trans.), Tehran, Mu'assasah Ilmi Farhangi.

Fanari, Muhammad bin Hamzah (1984), Misbāh al-Uns, Tehran, Intisharat Fajr. Ghazzali, Abu Hamid Muhammad (1964), Mishkāt al-Anwār, Cairo, al-Dar al-Qaumiyyah li al-Thaba'ah wa al-Nashr.

Hashimiyan, Hadi (2000), Daryā-e Irfān, Qom, Mu'assasah Farhangi Thaha.

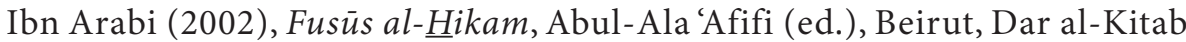
al-Arabi.

Ibn Arabi (2002), al-Futūh̄āt al-Makkiyyah, Beirut, Dar Ihya al-Turats al-Arabi.

Imam Khomeini (1989), Ta'līqāt 'alā Sharh Fusūs al-Hikam wa Misbāh al-Uns, Mu'assasah Pasdar Islami.

Imam Khomeini (1993), Misbāh al-Hidāyah ilā al-Khilāfah wa al-Wilāyah, Qom, Mu’assasah Tanzdim va Nashr Asar Imam Khomeini.

Imam Khomeini (1996), Tafsìr-e Süreh-e Hamd, Qom, Mu'assasah Tanzdim va Nashr Asar Imam Khomeini.

Imam Khomeini (1998), Sharh-e Hadits-e Junud-e 'Aql va Jahl, Qom, Mu'assasah Tanzdim va Nashr Asar Imam Khomeini.

Imam Khomeini (1999), Âdāb al-Salāh, Qom, Mu’assasah Tanzdim va Nashr Asar Imam Khomeini.

Imam Khomeini (2003), Nāmeh-ha-ye Irfānī, Tehran, Mu'assasah Tanzdim va Nashr Asar Imam Khomeini.

Imam Khomeini (2003), Sharh-e Chehel Hadits, Qom, Mu'assasah Tanzdim va Nashr Asar Imam Khomeini.

Kashani, Abdurrazzaq (1991), Istilā̄hāt al-Sūfyyah, Dr. Muhammad Kamal Ibrahim Ja'far (ed.), Qom, Bidar.

Kulabadzi, Abu Bakar Muhammad (1992), al-Ta'arruf li Madzhab Ahl al-Tasawwuf, Cairo, al-Maktabah al-Azhariyyah.

Lahiji, Muhammad (1995), Mafätīh al-I'jāz fì Sharh Gulshān-e Rāz, Entesharat Ketabfurushi Mahmudi.

Mulhall, Stephen (2005), Heidegger and Being and Time, New York, Routledge.

Muthahhari, Murtadha (1987), Maqālāt-e Falsafi, Tehran, Hikmat.

Muthahhari, Murtadha (1991), Sharh-e Ilähiyyât al-Shifä), Tehran, Intisharat Hikmat. 
Nayshaburi, Fariduddin Aththar (1997), Tadzkirat al-Awliyä', Nicolson (ed.), Tehran, Intisharat Milad.

Otto, Rudolf (2003), Mysticism, East and West, Wisconsin, Kessinger Publishing. Qunawi, Sadruddin (1984), Miftāh al-Ghayb, Tehran, Intisharat Fajr.

Qushairi, Abdulkarim (1995), al-Risālat al-Qushairiyyah, diteliti oleh Abdulhalim Khadum \& Mahmud bin Sharif, Qom, Intisharat Bidar.

Sarraj al-Thusi, Abu Nasr (2003), al-Luma' fì al-Tasawwuf, Tehran, Intisharat Asatir.

Saduq, Muhammad bin Ali bin Babiweih (1977), al-Tawhìd, Qom, Mu'assasah Nashr Islami.

Saduq, Muhammad bin Ali bin Babiweih (1998), Mâ̂nî al-Akhbâr, Ali Akbar Ghaffari (ed.), Qom, Mu'assasah Nashr Islami

Shahabadi, Mirza Muhammad Ali (2001), Shadzarāt al-Ma'ārif, Tehran, Setad Buzurghdasht Maqam Irfan va Shahadat.

Shahabadi, Mirza Muhammad Ali (1981), Rashahāt al-Bihhār, Tehran, Nehdhat-e Zanan Musalman.

Shirvani, Ali (2003), Farā-Akhlāq, Tehran, Pezhuheshgah Farhang va Andisheh Islami.

Stace, Walter T. (1960), Mysticism and Philosophy, Palgrave Macmillan.

Suhrawardi, Shihabuddin (1994), Musannafāt Sheikh Ishrāq, Tehran, Pezhuheshgah Ulum-e Insani va Mutaleat-e Farhangi.

Shirazi, Sadruddin Muhammad (1981), al-Asfār al-Arba'ah, Beirut, Dar Ihya al-Turats al-Arabi.

Shirazi, Sadruddin Muhammad (1982), Îqāzd al-Näimīn (1982), Tehran, Mu'assasah Mutaleat va Tahqiqat Farhangi.

Tabatabaei, Muhammad Husain (1997), al-Mīzān fì Tafsìr al-Qur'ān, Beirut, Mu’assasah al-Alami li al-Mathbu'at.

Tabatabaei, Muhammad Husain (1995), al-Rasāil al-Tawhīidiyyah, Qom, Mu'assasah al-Nashr al-Islami li Jama'ah al-Mudarrisin.

Turkah, Sainuddin (1981), Tamhìd al-Qawā'id, Jalaluddin Ashtiyani (ed.), Tehran, Intisharat Anjumen Islami Hikmat va Falsafeh Iran.

Yazdanpanah, Yadullah (2009), Mabānī va Usūl-e 'Erfān-e Nazdarī, Qom, Mu'assasah Amuzeshi va Pezhuheshi Imam Khomeini. 